\title{
Keanekaragaman dan Biomassa Ikan Karang serta Keterkaitannya dengan Tutupan Karang Hidup di Perairan Manggis, Kabupaten Karangasem, Bali
}

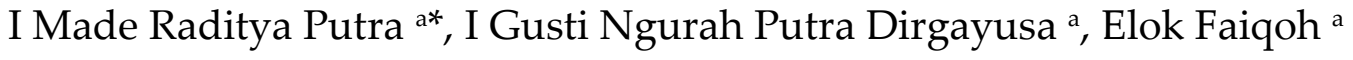 \\ a Program Studi Ilmu Kelautan, Fakultas Kelautan dan Perikanan, Universitas Udayana, Badung, Bali-Indonesia \\ * Penulis koresponden. Tel.: +62-813-383-02430 \\ Alamat e-mail: mdradityaputra@gmail.com
}

Diterima (received) 27 November 2017; disetujui (accepted) 16 Oktober 2018; tersedia secara online (available online) 18 Oktober 2018

\begin{abstract}
The existence of coral reef fish is closely related to the availability of coral reef resource as a habitat. Coral reef fish is a biota that has a fascination with a variety of color patterns and fascinating. Differences in coral cover conditions will affect the abundance of coral reef fish, especially those with strong linkages to living corals. This research was conducted in June - August 2017 by using line intercept transect (LIT) method for coral cover percentage and visual census method for biodiversity and biomass of coral reef fish with 3 research stations in Manggis waters, Karangasem. From the research results, it shows that the diversity index ranged between $2.54-2.70$ which means the diversity of coral reef fish in the medium category and the stability of the community is in the medium. Furthermore, total biomass of coral reef fish ranged between $186,17-1692,08 \mathrm{~kg} /$ ha. The results stated that the percentage of live coral cover in Manggis waters ranged from 3.83\% to $12.44 \%$ which means that live coral cover is categorized as bad. A very strong positive correlation between living coral conditions and coral reef fish biomass was $92.42 \%$. Meanwhile, the relationship between living coral conditions and the diversity of coral reef fish had a strong positive correlation of $65.4 \%$. The diversity of coral reef fish in waters is not only caused by live coral cover; however, it is caused by coral reef ecosystems that are associated in the bottom of the waters.
\end{abstract}

Keywords: diversity; biomass; coral reef fish; live coral; influence; Manggis Waters

\begin{abstract}
Abstrak
Keberadaan ikan karang erat kaitannya dengan ketersediaan sumberdaya terumbu karang sebagai habitat. Ikan karang merupakan biota yang memiliki daya tarik dengan corak warna yang beragam dan mempesona. Perbedaan pada kondisi tutupan karang akan mempengaruhi kelimpahan ikan karang, terutama yang memiliki keterkaitan kuat dengan karang hidup. Penelitian ini dilaksanakan pada bulan Juni - Agustus 2017 dengan menggunakan metode line intercept transect (LIT) untuk persentase tutupan karang dan metode visual census untuk keanekaragaman dan biomassa ikan karang dengan 3 stasiun penelitian di perairan Manggis, Kabupaten Karangasem. Dari hasil penelitian, indeks keanekaragaman berkisar antara 2,54 - 2,70 yang berarti keanekaragaman ikan karang dalam kategori sedang dan kestabilan komunitas sedang. Dan total biomassa ikan karang berkisar antara 186,17 - 1692,08 kg/ha. Hasil penelitian juga menyatakan bahwa persentase tutupan karang hidup di perairan Manggis berkisar antara 3,83\% $12,44 \%$ yang berarti tutupan karang hidup masuk dalam kategori buruk. Diperoleh korelasi positif sangat kuat antara kondisi karang hidup dengan biomassa ikan karang sebesar 92,42\%. Sedangkan, hubungan antara kondisi karang hidup dengan keanekaragaman ikan karang memiliki korelasi yang positif kuat dengan pengaruh sebesar 65,4\%. Hal ini menunjukkan bahwa keanekaraaman ikan karang pada suatu perairan bukan hanya disebabkan oleh tutupan karang hidup, melainkan disebabkan oleh ekosistem terumbu karang yang berasosiasi di dasar perairan.
\end{abstract}

Kata Kunci: keanekaragaman; biomassa; ikan karang; karang hidup; pengaruh; Perairan Manggis 


\section{Pendahuluan}

Kecamatan Manggis merupakan daerah dengan beberapa spot wisata bawah air yang memiliki keindahan terumbu karang. Selain itu, Perairan Manggis juga merupakan daerah keluar masuk kapal, dimana telah beroperasi tiga jenis pelabuhan, yaitu pelabuhan wisata Tanah Ampo, pelabuhan penyeberangan Padangbai, dan pelabuhan bahan bakar (Perda Karangasem, 2012).

Keberadaan pelabuhan tersebut mengakibatkan perubahan lingkungan, seperti pada tahun 2015, terjadi tumpahan minyak di perairan Manggis yang berpengaruh terhadap biota dan secara tidak langsung berpengaruh terhadap berkurangnya jumlah wisata bawah air disana juga berkurangnya hasil tangkapan bagi para nelayan (Freshcms, 2015).

Biota yang terkena langsung terhadap perubahan lingkungan adalah terumbu karang dan ikan karang. Kelangsungan hidup ikan karang ini tergantung pada kondisi terumbu karang serta kondisi fisika, kimia, dan biologi perairan. Keberadaan ikan karang erat kaitannya dengan kondisi sumberdaya terumbu karang sebagai habitat. Ikan karang merupakan biota yang memiliki daya tarik dengan corak warna yang beragam dan mempesona. Banyaknya ikan karang pada suatu kawasan (biomassa) menggambarkan seberapa besar tingkat produktivitas yang dihasilkan kawasan tersebut.

Penelitian mengenai pengaruh tutupan karang terhadap biomassa ikan karang sudah pernah dilakukan di kabupaten Karangasem khususnya di Perairan Amed. Dimana pada penelitian tersebut diperoleh tutupan Karang keras memiliki korelasi positif dengan biomassa ikan karang yaitu sebesar 66,4\% (Dananjaya, 2017). Sehingga meningkatnya persentase tutupan karang keras berpengaruh terhadap meningkatnya biomassa ikan karang di Perairan Amed, Kabupaten Karangasem, Bali. Penelitian ini belum pernah dilakukan di daerah Teluk Amuk, perairan Manggis.

Mengingat adanya kegiatan transportasi laut dan wisata bahari di kawasan perairan Manggis sehingga berpotensi adanya kerusakan terhadap kondisi terumbu karang dan ikan karang maka perlu dilakukan kajian ilmiah di daerah tersebut guna mengetahui kondisi alami di lingkungan perairan Karangasem khususnya di perairan Manggis. Penelitian ini bertujuan untuk mengetahui keanekaragaman dan biomassa ikan karang serta tutupan karang hidup di Perairan Manggis. Dan juga untuk mengetahui keterkaitan antara kondisi karang hidup dengan keanekaragaman dan biomassa ikan karang di Perairan Manggis.

\section{Metode Penelitian}

\subsection{Waktu dan Lokasi Penelitian}

Penelitian ini dilaksanakan pada bulan Juni Oktober 2017 di perairan Manggis, Kecamatan Manggis, Kabupaten Karangasem, Bali. Adapun stasiun yang diambil guna untuk penelitian meliputi Stasiun 1 (Tanah Ampo) yang merupakan kawasan pelabuhan khusus internasional, Stasiun 2 (Labuhan Amuk) yang merupakan kawasan wisata bahari dimana terdapat wisata kapal selam dan daerah bersandar perahu milik para nelayan, Stasiun 3 (Pantai Blue Lagoon) merupakan wisata pantai dan tempat untuk menyelam (diving) (Gambar 1).

\subsection{Prosedur Pengambilan Data}

\subsubsection{Pengambilan Data Terumbu Karang}

Metode yang digunakan untuk pengambilan persentase tutupan karang adalah metode line intercept transect (transek garis). Pada masingmasing stasiun pengamatan ditarik transek garis (roll meter) sepanjang $100 \mathrm{~m}$ tegak lurus dari garis pantai dan sebagai ulangan transek tersebut dibagi menjadi 2 transek dengan jarak antar ulangan $10 \mathrm{~m}$ pada kedalaman 5- $8 \mathrm{~m}$. Metode transek garis adalah metode pengamatan ekosistem terumbu karang yang menggunakan transek berupa meteran dengan prinsip pencatatan substrat dasar yang menyinggung transek (Purnomo, 2012).

\subsubsection{Pengambilan Data Ikan Karang}

Pengamatan ikan karang dilakukan dengan menggunakan metode sensus visual (Visual Census Method) (Hodgson, 1999). Masing-masing stasiun pengamatan ditarik transek garis (roll meter) sepanjang $100 \mathrm{~m}$ tegak lurus dari garis pantai dan sebagai ulangan transek tersebut dibagi menjadi 2 transek dengan jarak antar ulangan $10 \mathrm{~m}$ pada kedalaman 5- $8 \mathrm{~m}$.

Dengan pertimbangan waktu dan persediaan oksigen yang terbatas, kegiatan pendataan ikan 

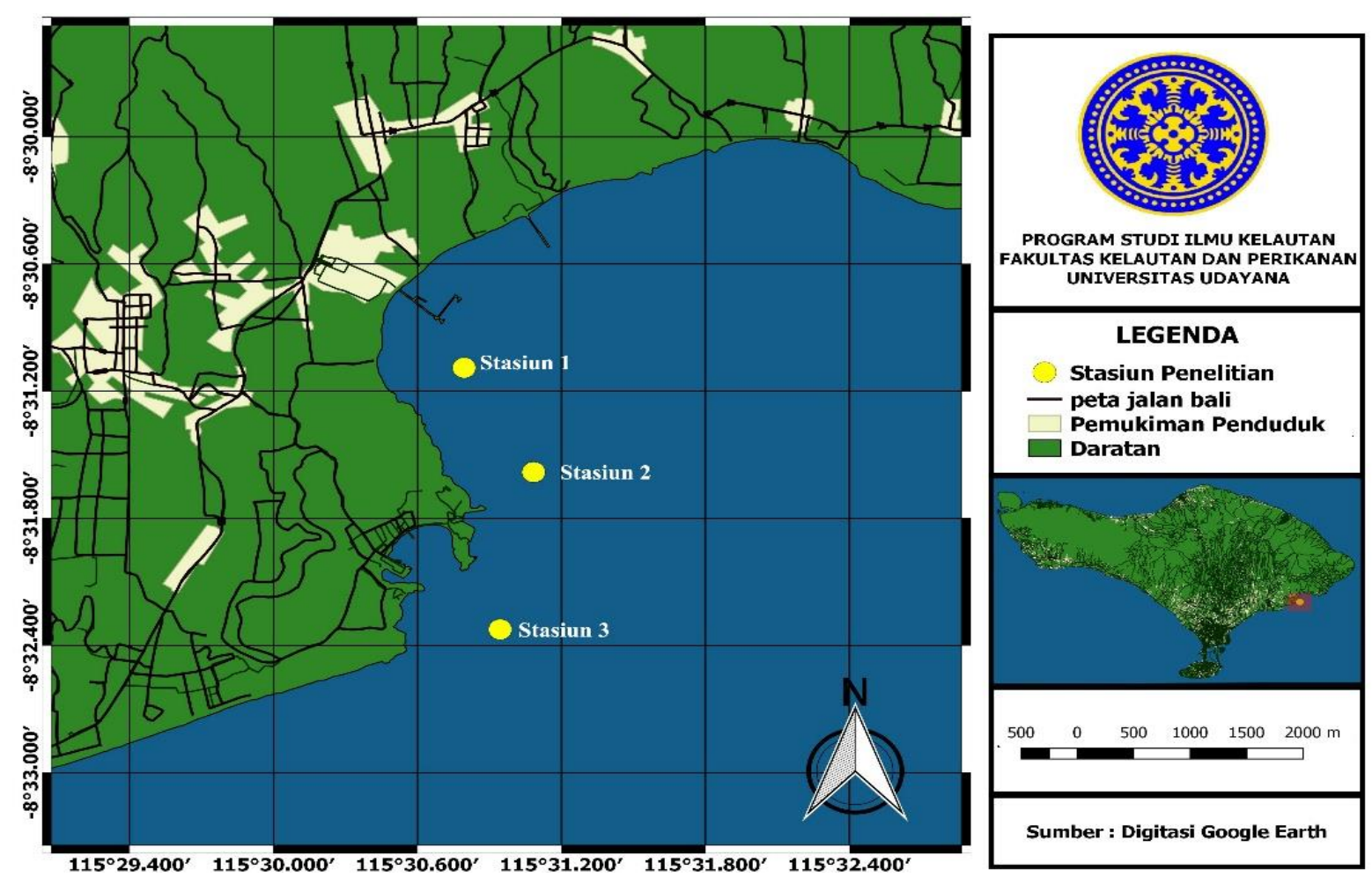

Gambar 1. Peta lokasi penelitian

karang dimulai beberapa menit setelah pemasangan transek. Kelimpahan ikan tiap jenis mulai dihitung dengan batasan jarak pantau 2,5 m pada sisi kiri dan kanan transek (Hodgson, 1999). Untuk pengamatan biomassa ikan, panjang ikan diestimasi dan dihitung jumlah kelimpahan tiap individu ikan (Gambar 2).

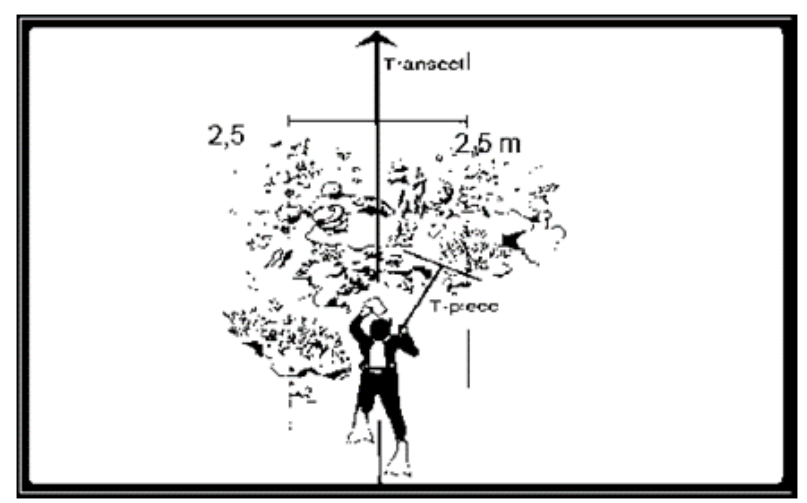

Gambar 2. Cara Melakukan Sensus Visual Ikan Karang

\subsection{Analisis Data}

\subsubsection{Penutupan Karang}

Analisis data meliputi perhitungan penutupan karang dan kelimpahan dari kategori kesehatan karang. Perhitungan penutupan karang diketahui dengan persamaan berikut:

$$
\text { Persentase tutupan }=\frac{\text { Panjang kategori tutupan }(\mathrm{cm})}{\text { Panjang transek }(\mathrm{cm})} \times 100 \%
$$

Untuk mengetahui kategori persen tutupan karang hidup dengan pengkategorian menurut Keputusan Menteri Lingkungan Hidup No. 4 Tahun 2001 tentang Kriteria Baku Kerusakan Terumbu Karang sebagai berikut:

Tabel 1

Kriteria Baku Kerusakan Terumbu Karang

\begin{tabular}{cccc}
\hline Parameter & \multicolumn{2}{c}{ Kriteria Baku Kerusakan Terumbu Karang } \\
& \multicolumn{3}{c}{$\%)$} \\
\hline Presentase & Rusak & Buruk & $0-24.9$ \\
Luas & & Sedang & $25-49.9$ \\
Tutupan & Baik & Baik & $50-74.9$ \\
Terumbu & & Baik Sekali & $75-100$ \\
Karang & & & \\
Hidup & & & \\
\hline
\end{tabular}

\subsubsection{Ikan Karang}

a. Komposisi Jenis (KJ) dan Kelimpahan

$\mathrm{KJ}=\frac{n i}{\boldsymbol{N}} \times 100 \%$ 
dimana: $\mathrm{KJ}=$ Komposisi jenis $(\%), \mathrm{ni}=$ Jumlah individu setiap jenis, $\mathrm{N}=$ Jumlah individu seluruh jenis. Kelimpahan ikan karang dihitung dengan mendata jumlah ikan (ekor) untuk setiap jenis dan kelompok ikan dinyatakan dalam jumlah individu perstasiun.

\section{b. Indeks Keanekaragaman}

Indeks keanekaragaman jenis adalah suatu pernyataan atau penggambaran secara matematik yang melukiskan struktur kehidupan dan dapat mempermudah menganalisa informasi-informasi tentang jenis dan jumlah organisme. Penghitungan indeks keanekaragaman ikan karang dilakukan dengan menggunakan Indeks Shannon-Wiener (Dhahiyat, 2017) yaitu:

$$
H^{\prime}=-\sum_{i=1} P i \ln P i, \operatorname{dimana} P i=\frac{n i}{n}
$$

dimana: $\mathrm{H}^{\prime}$ : Indeks Keanekaragaman, ni: Jumlah individu jenis ke-1, n: Jumlah individu total

\section{Tabel 2}

Penggolongan kondisi komunitas biota berdasarkan $\mathrm{H}^{\prime}$ adalah:

\begin{tabular}{ccc}
\hline Indeks & Kisaran & Kategori \\
\hline \multirow{3}{*}{ Keanekaragaman } & $\mathrm{H}^{\prime}<2,30$ & Kecil \\
& $2,30<\mathrm{H}^{\prime}<6,91$ & Sedang \\
& $\mathrm{H}^{\prime}>6,91$ & Tinggi \\
\hline
\end{tabular}

\section{c. Biomassa Ikan Karang}

Pendataan biomassa ikan karang dilakukan dengan mengestimasi panjang ikan dari ujung mulut hingga pangkal ekor (fork length) kemudian dimasukkan dalam perhitungan biomassa ikan karang sesuai kaidah Kulbicki et al. (2005) yaitu:

$$
W=a L^{b}
$$

dimana: $\mathrm{W}=$ berat ikan dalam gram; $\mathrm{L}=$ estimasi panjang ikan (fork length) dalam $\mathrm{cm}$; a dan $\mathrm{b}=$ nilai konstanta spesies ikan.

Setelah mengetahui nilai biomassa tiap spesies, kemudian dilakukan perhitungan total biomassa ikan karang per transek. Perhitungan dilakukan dengan menggunakan persamaan:

$$
\text { Total biomassa per transek }=\frac{W 1+W 2+\cdots+W n}{\text { luas transek }}
$$

dimana: W1, W2, hingga Wn adalah biomassa satu ekor ikan dalam gram. Kemudian, data yang telah diperoleh dikonversi kedalam satuan kilogram per hektar. d. Hubungan karang hidup dengan keanekaragaman dan biomassa ikan karang

Untuk mengetahui hubungan tutupan karang hidup dengan keanekaragaman dan biomassa ikan karang, data yang diperoleh berupa persentase tutupan life form karang hidup, indeks keanekaraaman ikan karang dan total berat biomassa ikan karang, ditabulasi dan disajikan dalam bentuk gambar dan grafik sehingga diketahui kecendrungan yang tejadi. Selanjutnya data tesebut dianalisis secara deskriptif dengan berpedoman pada hasil-hasil penelitian sejenis dan data sekunder lainnya.

Tabel 3

Kriteria korelasi menurut Mulyadi (2011):

\begin{tabular}{ll}
\hline \multicolumn{1}{c}{$\mathrm{R}$} & \multicolumn{1}{c}{ Kriteria hubungan } \\
\hline$<0,20$ & Hubungan dapat dianggap tidak ada \\
$0,20-0,40$ & Hubungan ada tetapi lemah \\
$>0,40-0,70$ & Hubungan cukup \\
$>0,70-0,90$ & Hubungan kuat \\
$>0,90-1,00$ & Hubungan sangat kuat \\
\hline
\end{tabular}

\section{Hasil dan Pembahasan}

\subsection{Hasil}

\subsubsection{Gambaran Umum Stasiun Penelitian}

Perairan manggis merupakan salah satu kawasan pesisir yang dimiliki oleh kabupaten Karangasem. Secara geografis manggis terletak pada posisi $8^{\circ 2} 9^{\prime} 29.40^{\prime \prime}$ LS dan $115^{\circ} 31^{\prime} 30.52^{\prime \prime}$ BT. Secara umum di stasiun penelitian terdapat hamparan ekosistem terumbu karang alami, sehingga di perairan manggis terdapat beberapa tempat untuk berwisata bahari, diantaranya wisata kapal selam, diving, dan snorkeling. Selain itu manggis juga memiliki pelabuhan dan dermaga kapal yang masih aktif hingga saat ini. Secara umum masyarakat yang tinggal di kawasan ini berprofesi sebagai nelayan yang beroperasi sendiri-sendiri maupun berkelompok umumnya mencari ikan di sekitar perairan menggunakan perahu mesin. Sebagian masyarakat di perairan manggis juga mengelola wisata bahari yang ada kawasan perairan tersebut. 

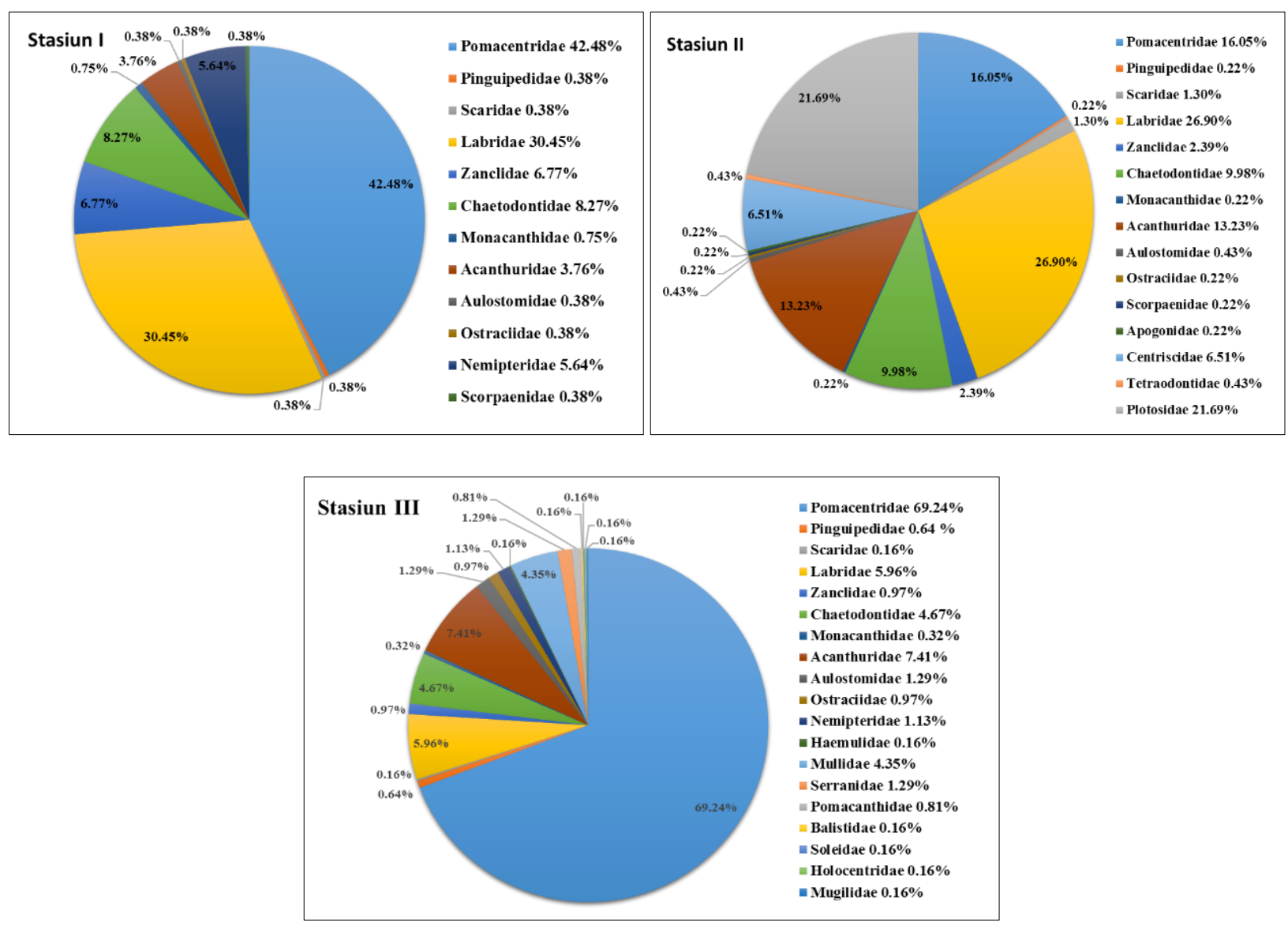

Gambar 3. Persentase Komposisi Jenis Ikan Karang berdasarkan Famili pada stasiun penelitian.

3.1.2. Komposisi Jenis Ikan Karang berdasarkan Famili

Dilihat pada Gambar 3, dari keseluruhan jumlah ikan karang yang di peroleh pada stasiun I, Famili Pomacentridae memiliki jumlah persentase tertinggi yaitu sebesar 42,48\%. Ikan yang mendominasi adalah dari spesies Abudefduf vaigiensis dengan total spesies yang di peroleh pada stasiun I sejumlah 55 individu ikan. Kemudian pada stasiun II, famili Labridae memiliki persentase tertinggi sebesar 26,90\% dengan ikan yang mendominasi adalah dari spesies Thalassoma hardwicke dengan total spesies yang di peroleh pada stasiun II sejumlah 86 individu ikan. Stasiun III memiliki jumlah famili terbanyak dari stasiun I dan stasiun II yaitu 19 famili dengan total individu 621 individu. Dilihat pada Gambar 3, persentase tertinggi komposisi ikan karang yaitu famili Pomacentridae hingga mencapai 69,24\%. Sama dengan stasiun I, Famili Pomacentridae mendominasi dengan persentase sebesar 69,24\% dari spesies Chromis margaritifer sebanyak 155 individu ikan.
3.1.3. Pengelompokan Ikan Karang berdasarkan Peranannya

Berdasarkan peranannya pada Tabel 4, terlihat bahwa jumlah famili dan spesies pada ikan target terbanyak adalah pada stasiun III dengan 5 famili dan 16 spesies ikan target dibandingkan dengan stasiun I hanya 2 famili 4 spesies dan stasiun II sebanyak 2 famili 7 spesies. Sama halnya dengan ikan target, pada ikan indikator di stasiun III memiliki jumlah spesies terbanyak yaitu 8 spesies, sedangkan stasiun I hanya sebanyak 4 spesies dan stasiun II sebanyak 7 spesies. Pada ikan mayor, juga sama dengan ikan target maupun ikan indikator yaitu di stasiun III memiliki famili dan spesies terbanyak yaitu 13 famili dengan 27 spesies. Kemudian terbanyak kedua pada stasiun II sebanyak 12 famili dengan 20 spesies. Dan terakhir stasiun I sebanyak 9 famili dengan 15 spesies.

\subsubsection{Tutupan Karang}

Tutupan dasar terumbu karang di lokasi penelitian di dominasi oleh 3 komponen yaitu unsur Karang 
mati, abiotik dan biota lain. Karang mati tertinggi yaitu pada stasiun I sebesar 40,79\% dibanding

Tabel 4

Kelompok Ikan Karang berdasarkan peranannya pada stasiun penelitian.

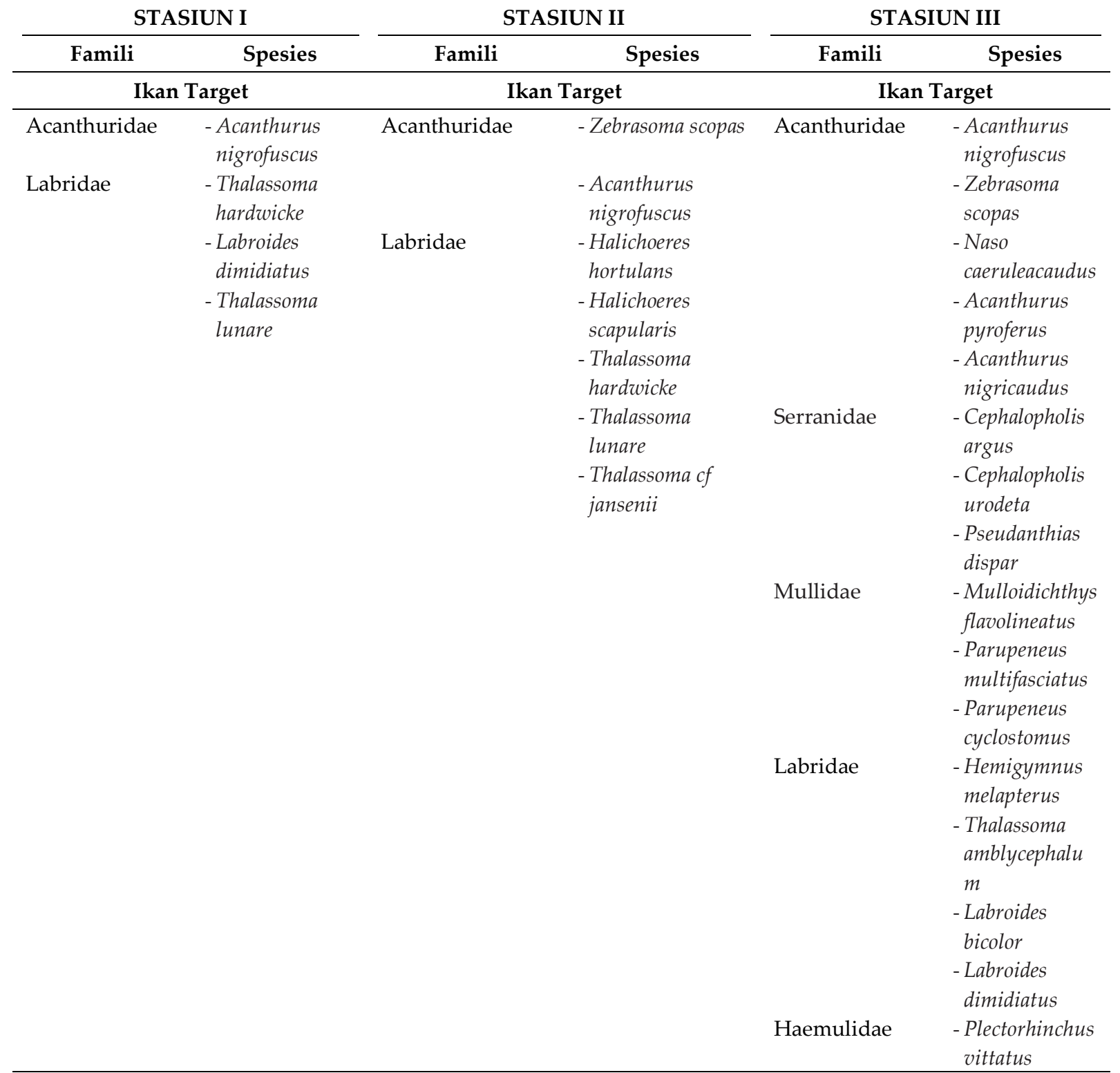

\begin{tabular}{|c|c|c|c|c|c|}
\hline \multicolumn{2}{|c|}{ Ikan Indikator } & \multicolumn{2}{|c|}{ Ikan Indikator } & \multicolumn{2}{|c|}{ Ikan Indikator } \\
\hline Chaetodontidae & $\begin{array}{l}\text { - Chaetodon } \\
\text { trifasciatus } \\
\text { - Chaetodon } \\
\text { vagabundus } \\
\text { - Chaetodon } \\
\text { lunula } \\
\text { - Chaetodon } \\
\text { decussatus }\end{array}$ & Chaetodontidae & $\begin{array}{l}\text { - Chaetodon } \\
\text { ulietensis } \\
\text { - Chaetodon } \\
\text { vagabundus } \\
\text { - Chaetodon kleinii } \\
\\
\text { - Chaetodon } \\
\text { trifacialis } \\
\text { - Chaetodon } \\
\text { trifasciatus } \\
\text { - Chaetodon } \\
\text { deccusatus } \\
\text { - Chaetodon lunula }\end{array}$ & Chaetodontidae & $\begin{array}{l}\text { - Chaetodon } \\
\text { trifasciatus } \\
\text { - Chaetodon } \\
\text { lunula } \\
\text { - Chaetodon } \\
\text { ocellicaudus } \\
\text { - Chaetodon } \\
\text { adiergastos } \\
\text { - Chaetodon } \\
\text { lineolatus } \\
\text { - Chaetodon } \\
\text { kleinii } \\
\text { - Heniochus } \\
\text { varius } \\
\text { - Chaetodon } \\
\text { speculum } \\
\end{array}$ \\
\hline \multicolumn{2}{|c|}{ Ikan Mayor } & \multicolumn{2}{|c|}{ Ikan Mayor } & \multicolumn{2}{|c|}{ Ikan Mayor } \\
\hline Miromatapenttridiā: & $\begin{array}{c}\text {-Pomacentrus } \\
\text { 164-176(2019) } \\
\text { coelestis } \\
\text {-Chromis } \\
\text { margaritifer }\end{array}$ & Pomacentridae & $\begin{array}{l}\text {-Amphiprion } \\
\text { clarkii } \\
\text {-Pomacentrus } \\
\text { coelestis }\end{array}$ & Pomacentridae & $\begin{array}{l}\text {-Chromis } \\
\text { margaritifer } \\
\text {-Pomacentrus } \\
\text { coelestis }\end{array}$ \\
\hline
\end{tabular}


stasiun II dan stasiun III. Karang mati di perairan Manggis didominasi oleh karang mati yang di tumbuhi oleh alga (DCA). Selain karang mati juga terdapat unsur abiotik yang mendominasi di lokasi penelitian. Abiotik tertinggi dari ketiga stasiun adalah di stasiun II sebesar 53,92\%. Abiotik

Tabel 4 lanjutan...

\begin{tabular}{|c|c|c|c|c|c|}
\hline \multicolumn{2}{|c|}{ Ikan Mayor } & \multicolumn{2}{|c|}{ Ikan Mayor } & \multicolumn{2}{|c|}{ Ikan Mayor } \\
\hline \multirow[t]{11}{*}{ Pomacentridae } & - Pomacentrus & Pomacentridae & - Amphiprion clarkii & Pomacentridae & $\begin{array}{l}\text { - Chromis } \\
\text { maroaritifer }\end{array}$ \\
\hline & - Chromis & & - Pomacentrus & & - Pomacentrus \\
\hline & - Abudefduf & & - Chromis & & - Dascyllus \\
\hline & vaigiensis & & margaritifer & & trimaculatus \\
\hline & - Pomacentrus & & - Neopomacentrus & & - Pomacentrus \\
\hline & moluccensis & & violascens & & moluccensis \\
\hline & - Pomacentrus & & - Pomacentrus & & - Dascyllus \\
\hline & bankanensis & & moluccensis & & reticulatus \\
\hline & - Ablyglyphidodon & & - Dascyllus & & - Chromis \\
\hline & curacao & & trimaculatus & & amboinensis \\
\hline & - Amphiprion & & - Dascyllus & & - Pomacentrus \\
\hline Pinguipedidae & $\begin{array}{l}\text { - Parapercis } \\
\text { xanthozona }\end{array}$ & & $\begin{array}{l}\text { - Plectroglyphidodon } \\
\text { lacrymatus }\end{array}$ & & $\begin{array}{l}\text { - Amphiprion } \\
\text { clarkii }\end{array}$ \\
\hline Scaridae & $\begin{array}{l}\text { - Chlorurus } \\
\text { sordidus }\end{array}$ & Pinguipedidae & $\begin{array}{l}\text { - Parapercis } \\
\text { xanthozona }\end{array}$ & & $\begin{array}{l}\text { - Amphiprion } \\
\text { ocellaris }\end{array}$ \\
\hline Zanclidae & $\begin{array}{l}\text { - Zanclus } \\
\text { cornutus }\end{array}$ & Centriscidae & $\begin{array}{l}\text { - Centriscus } \\
\text { scutatus }\end{array}$ & Nemipteridae & $\begin{array}{c}\text {-Scolopsis } \\
\text { bilineata }\end{array}$ \\
\hline Monacanthidae & $\begin{array}{l}\text { - Paraluteres } \\
\text { prionurus }\end{array}$ & Ostraciidae & $\begin{array}{c}\text { - Ostracion } \\
\text { meleagris }\end{array}$ & Zanclidae & $\begin{array}{l}\text { - Zanclus } \\
\text { cornutus }\end{array}$ \\
\hline Nemipteridae & $\begin{array}{c}\text { - Scolopsis } \\
\text { bilineata }\end{array}$ & Zanclidae & - Zanclus cornutus & Aulostomidae & $\begin{array}{l}\text { - Aulostomus } \\
\text { chinensis }\end{array}$ \\
\hline Aulostomidae & $\begin{array}{l}\text { - Aulostomus } \\
\text { chinensis }\end{array}$ & Plotosidae & - Plotosus lineatus & Ostraciidae & $\begin{array}{c}\text { - Ostracion } \\
\text { meleagris }\end{array}$ \\
\hline Ostraciidae & $\begin{array}{l}\text { - Rhychostracion } \\
\text { rhinorhynchos }\end{array}$ & Monacanthidae & $\begin{array}{l}\text { - Paraluteres } \\
\text { prionurus }\end{array}$ & & $\begin{array}{l}\text { - Tetrosomus } \\
\text { gibbosus }\end{array}$ \\
\hline \multirow[t]{11}{*}{ Scorpaenidae } & $\begin{array}{l}\text { - Scorpaenopsis } \\
\text { oxycephala }\end{array}$ & Tetraodontidae & - Arothron mappa & & $\begin{array}{l}\text { - Ostracion } \\
\text { cubicus }\end{array}$ \\
\hline & & & $\begin{array}{l}\text { - Arothron } \\
\text { manilensis }\end{array}$ & Pinguipedidae & $\begin{array}{l}\text { - Parapercis } \\
\text { xanthozona }\end{array}$ \\
\hline & & Scaridae & $\begin{array}{l}\text { - Chlorurus } \\
\text { sordidus }\end{array}$ & & $\begin{array}{l}\text { - Parapercis } \\
\text { hexophtalma }\end{array}$ \\
\hline & & Scorpaenidae & $\begin{array}{l}\text { - Dendrochirus } \\
\text { zebra }\end{array}$ & Scaridae & $\begin{array}{l}\text { - Scarus } \\
\text { ghobban }\end{array}$ \\
\hline & & Apogonidae & - Cheilodipterus sp 1 & Pomacanthidae & $\begin{array}{l}\text { - Centropyge } \\
\text { bicolor }\end{array}$ \\
\hline & & Aulostomidae & $\begin{array}{l}\text { - Aulostomus } \\
\text { chinensis }\end{array}$ & & $\begin{array}{l}\text { - Pomacanthus } \\
\text { xanthometopon }\end{array}$ \\
\hline & & & & Balistidae & $\begin{array}{l}\text { - Sufflamen } \\
\text { chrysopterus }\end{array}$ \\
\hline & & & & Soleidae & $\begin{array}{l}\text { - Pardachirus } \\
\text { pavoninus }\end{array}$ \\
\hline & & & & Monacanthidae & $\begin{array}{l}\text { - Cantherhines } \\
\text { pardalis } \\
\text { - Cantherhines } \\
\text { fronticinctus }\end{array}$ \\
\hline & & & & Holocentridae & $\begin{array}{l}\text { - Myripristis } \\
\text { aulacodes }\end{array}$ \\
\hline & & & & Mugilidae & $\begin{array}{l}\text { - Crenimugil } \\
\text { crenilabis }\end{array}$ \\
\hline
\end{tabular}


yang dimaksud pada tutupan dasar terumbu karang di stasiun II adalah terdapat banyak patahan karang dan pasir. Unsur ketiga yang mendominasi tutupan dasar terumbu karang di lokasi penelitian adalah biota lain. Biota lain mendominasi pada stasiun I sebesar 41,06\% dibandingkan stasiun lainnya. Hal ini dikarenakan pada stasiun I terdapat banyak Karang lunak (soft coral), zoanthids dan gorgonian (Gambar 4).

\subsubsection{Indeks Keanekaragaman Ikan Karang}

Pada dasarnya, keanekaragaman ikan karang di terumbu karang sangat berpengaruh terhadap keseimbangan ekosistem yang ada di dasar perairan. Berdasarkan hasil pengamatan secara langsung dan perhitungan data-data penelitian, diperoleh nilai indeks keanekaragaman $(\mathrm{H})$ pada stasiun I sebesar 2,56, pada stasiun II sebesar 2,54 dan pada stasiun III sebesar 2,70 yang dapat dilihat pada Gambar 5.

Hal ini menunjukkan bahwa keanekaragaman ikan karang pada ketiga stasiun berada pada kisaran kriteria 2,30< $\mathrm{H}^{\prime}<6,91$ yang berarti keanekaragaman spesies ikan karang yang ditemukan pada ketiga stasiun termasuk dalam kategori sedang dan memiliki kestabilan komunitas sedang. Dan keanekaragaman tertinggi terdapat pada stasiun III yaitu sebesar 2,70.

\subsubsection{Biomassa Ikan Karang}

Dari hasil penelitian dan perhitungan data, dapat dilihat pada Tabel 5 dengan biomassa total dari ketiga stasiun diperoleh stasiun I sebanyak 186,17 $\mathrm{kg} /$ ha, stasiun II sebanyak 509,12 kg/ha dan stasiun III sebanyak 1692,08 kg/ha. Sehingga jumlah total biomassa terbanyak yaitu pada stasiun III sebanyak 1692,08 kg/ha dimana pada transek 1 mencapai hingga 1577,93 kg/ha sedangkan transek 2 hanya sebanyak $114,15 \mathrm{~kg} / \mathrm{ha}$.

Tabel 5

Total berat Biomassa Ikan Karang di stasiun penelitian

\begin{tabular}{lcccc}
\hline \multirow{2}{*}{ No } & & \multicolumn{3}{c}{ Stasiun } \\
& & I (kg/ha) & II (kg/ha) & III (kg/ha) \\
\hline \multirow{2}{*}{ Transek } & 1 & 149.52 & 311.41 & 1577.93 \\
& 2 & 36.65 & 197.71 & 114.15 \\
\hline Jumlah & & 186.17 & 509.12 & 1692.08 \\
Rata-Rata & 93.085 & 254.56 & 846.04 \\
\hline
\end{tabular}

3.1.7. Pengaruh Persentase Tutupan Karang Hidup terhadap Biomassa dan Indeks Keanekaragaman Ikan Karang pada stasiun penelitian.

Untuk melihat hubungan antara kedua variabel berbeda dilakukan analisis korelasi dan untuk mengetahui seberapa besar pengaruhnya dilakukan analisis regresi polinomial. Variabel bebas diwakili oleh persentase tutupan karang hidup sedangkan variabel terikat diwakili oleh biomassa ikan karang dan indeks keanekaragaman ikan karang. Hasil analisis korelasi menunjukkan adanya hubungan yang positif sangat kuat antara

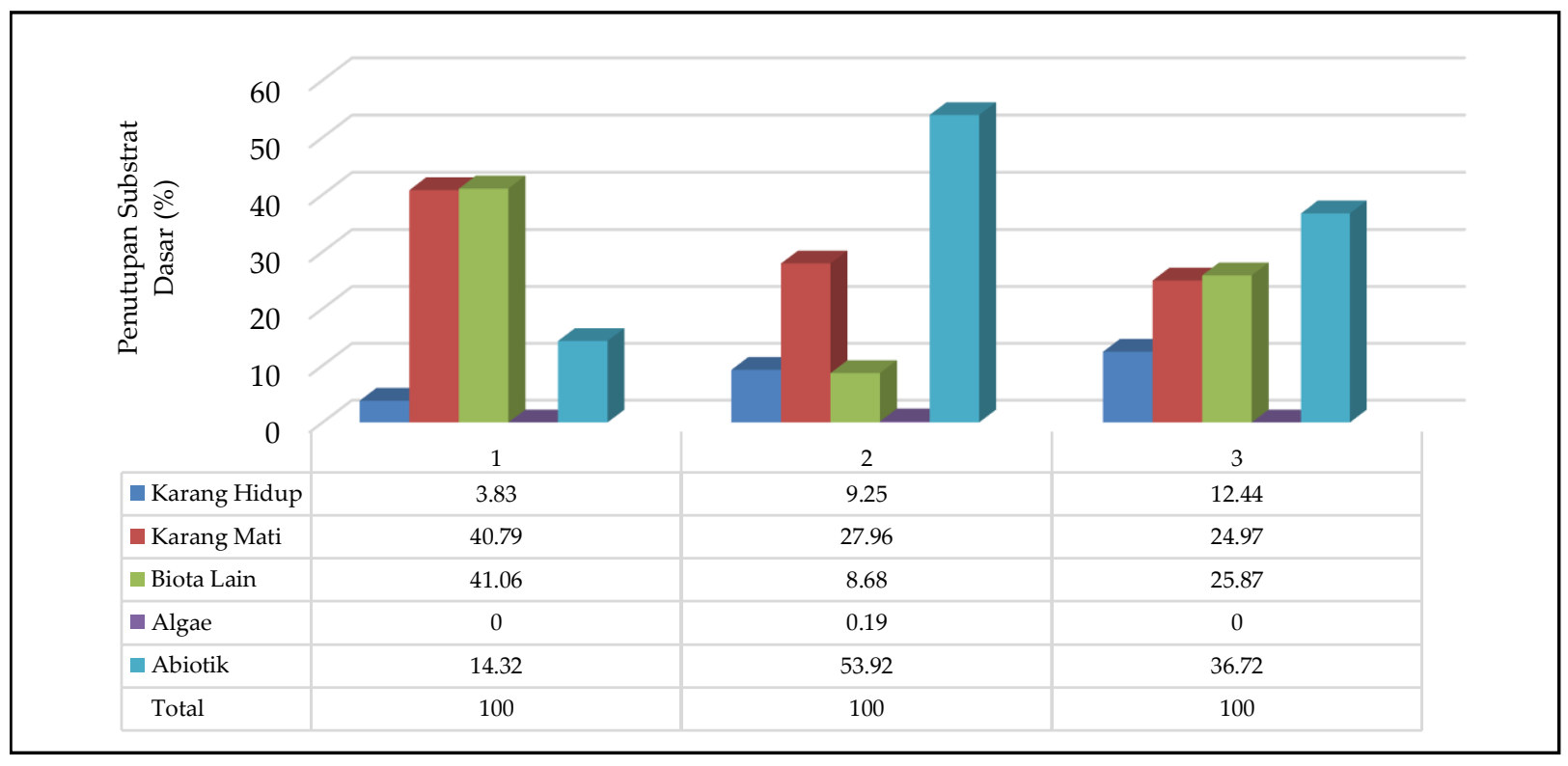

Gambar 4. Peta lokasi penelitian 
variabel karang hidup dengan biomassa ikan karang yaitu dengan diperoleh nilai korelasi $\mathrm{R}=$ 0,9613 . Hasil regresi polinomial menghasilkan $\mathrm{y}=$ $13.55 \mathrm{x}^{2}-139.19 \mathrm{x}+361.21$ dengan koefisien determinasi $\mathrm{R}^{2}=0.9242$. Koefisien determinasi tersebut menunjukkan bahwa meningkatnya variabel persentase tutupan karang hidup juga diiringi dengan meningkatnya variabel biomassa ikan karang yang menandakan adanya pengaruh sebesar $R^{2}=0.9242$ atau karang hidup memengaruhi sebesar $92,42 \%$ terhadap biomassa ikan karang di seluruh stasiun penelitian di perairan Manggis (Gambar 6).

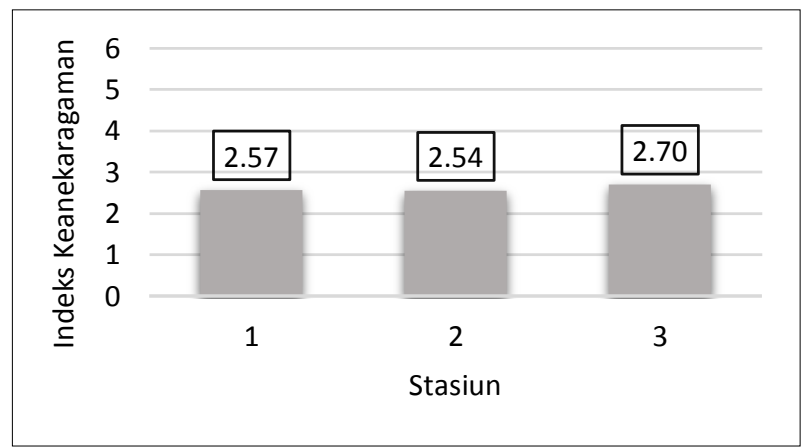

Gambar 5. Indeks Keanekaragaman Ikan Karang di Stasiun I, II, dan III.

Sedangkan antara variabel karang hidup dengan indeks keanekaragaman ikan karang hasil analisis korelasi menunjukkan adanya hubungan yang positif kuat yaitu dengan diperoleh nilai korelasi $\mathrm{R}=0,8087$. Hasil regresi polinomial menghasilkan $y=0.0107 x^{2}-0.1531 x+2.5079$ dengan koefisien determinasi $\mathrm{R}^{2}=0.654$. Koefisien determinasi tersebut menunjukkan bahwa meningkatnya variabel persentase tutupan karang hidup juga berpengaruh terhadap variabel indeks keanekaragaman ikan karang dengan pengaruh sebesar $65,4 \%$ di seluruh stasiun penelitian di perairan Manggis (Gambar 7).

\subsection{Pembahasan}

Sesuai dengan pengkategorian menurut Keputusan Menteri Lingkungan Hidup No. 4 Tahun 2001 tentang Kriteria Baku Kerusakan Terumbu Karang, tutupan karang hidup pada ketiga stasiun tergolong buruk karena berada dibawah $25 \%$. Hal ini diduga akibat dari adanya aktivitas transportasi laut yang berada di kawasan penelitian, dimana terdapat pelabuhan penyebrangan dan pelabuhan dengan fungsi pelayanan pengangkutan bahan bakar di areal stasiun penelitian. Menurut Edrus (2017), kerusakan ekosistem terumbu karang diakibatkan oleh adanya aktivitas transportasi laut yang berlabuh dengan pelemparan jangkar kapal di kawasan tersebut. Selain itu pendaratan kapal yang tidak sengaja pada kawasan terumbu karang juga berdampak buruk bagi ekosistem terumbu karang.

Dilihat pada Gambar 4, karang hidup di stasiun I terendah dan hanya mencapai 3,83\% dan yang mendominasi pada stasiun I adalah biota lain (karang lunak). Tingginya kepadatan karang lunak salah satunya dipengaruhi oleh kedalaman dan

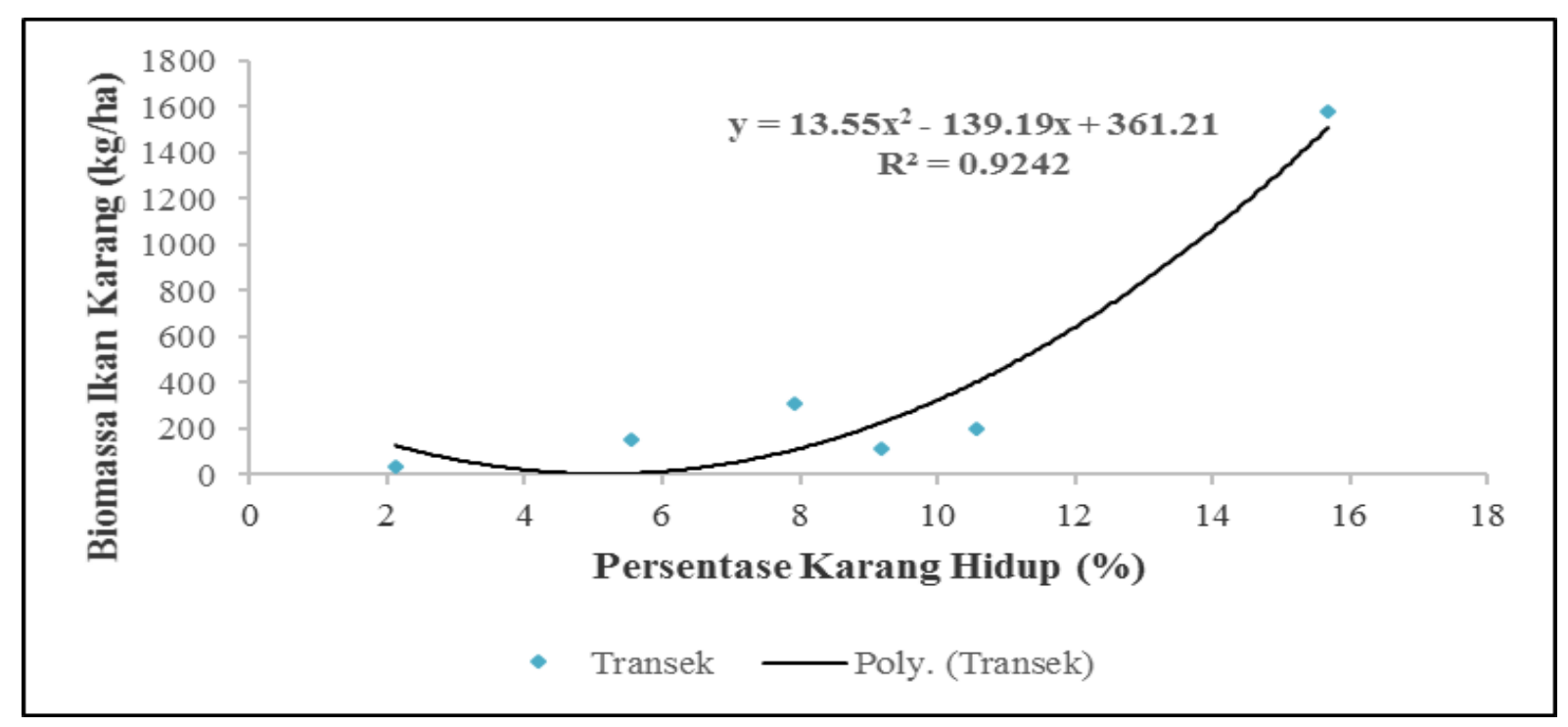

Gambar 6. Pengaruh persentase tutupan karang hidup terhadap biomassa ikan karang. 


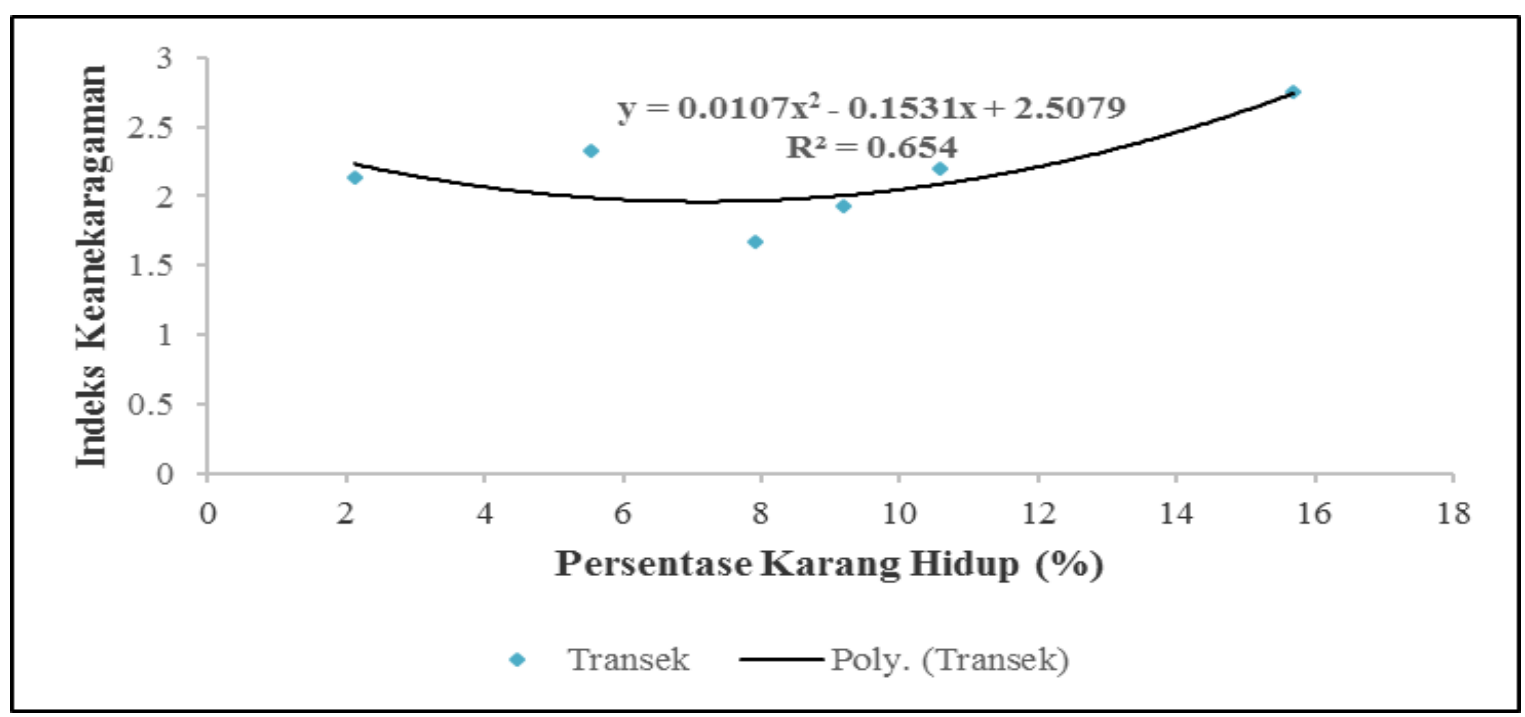

Gambar 7. Pengaruh persentase tutupan karang hidup terhadap Indeks Keanekaragaman ikan karang.

kepadatan karang lunak yang cenderung lebih tinggi pada kedalaman $3 \mathrm{~m}$ dimana intensitas cahaya yang masuk ke perairan sangat baik untuk pertumbuhan dan persediaan makanan (plankton) untuk karang lunak (Mardianto et al., 2016). Sama halnya dengan penelitian yang dilakukan oleh Subhan et al. (2012), dimana karang lunak yang di pelihara di kolam terbuka (cahaya) bertahan hidup hingga akhir penelitian dibandingkan dengan karang lunak yang dipelihara di kolam tertutup (tanpa cahaya). Hal ini dikarenakan karang mengalami stress akibat gagal melakukan adaptasi dengan kondisi lingkungan tanpa cahaya. Sehingga cahaya berpengauh terhadap pertumbuhan dan persediaan makan untuk karang lunak.

Spesies yang mendominasi di stasiun I adalah dari spesies Abudefduf vaigiensis dimana kebiasaan makannya omnivora dengan jenis makanan adalah zooplankton, alga bentik, dan invertebrata. Hal ini disebabkan oleh tingginya biota lain (soft coral, zoanthid, dll) dan karang mati yang di tumbuhi oleh alga (DCA) pada stasiun I sehingga asupan makanan untuk famili Pomacentridae khususnya pada Abudefduf vaigiensis dapat terjaga dengan baik. Spesies Abudefduf vaigiensis berwarna abuabu kehitaman dengan 5 garis biru (termasuk garis di dasar ekor) biasa didapatkan warna kuning diatas punggung, dan biasanya membentuk kelompok makan di pertengahan air atau biasa menjaga sarang di dalam celah-celah berbatu (Nasution, 2016).

Pada stasiun II komposisi jenis di dominasi oleh famili Labridae dengan persentase sebesar 26,90\% dan spesies yang mendominasi adalah Thalassoma hardwicke. Thalassoma hardwicke merupakan jenis ikan karang dengan kebiasaan makanan karnivora yaitu pemakan krustasea, ikan kecil dan foraminifera. Hal ini diduga dengan hasil tutupan terumbu karang dimana pada stasiun II yang mendominasi adalah dari komponen abiotik (patahan karang, pasir) hingga mencapai 53,92\%, sehingga ikan dari famili Labridae dapat bertahan hidup dari banyaknya biota yang tinggal di patahan karang, terutama ikan kecil, krustasea, dan kekerangan serta biota yang lainnya. Menurut Arthana (2009) ikan-ikan jenis Labridae hampir dijumpai di semua ekosistem karang. Makanan utamanya adalah invertebrata kecil baik di dasar maupun di pertengahan perairan.

Komposisi jenis ikan karang berdasarkan famili di stasiun III memiliki jumlah famili terbanyak dari stasiun I dan stasiun II yaitu 19 famili dengan total individu 621 ekor. Hal ini dikarenakan tutupan terumbu karang hidup di stasiun III juga memiliki persentase tertinggi dari stasiun I dan stasiun II (Gambar 3). Menurut Rembet et al. (2011), terumbu karang dominan tersusun dari karang keras yang berfungsi sebagai tempat tinggal dan tempat berlindung bagi sebagian besar biota laut yang berasosiasi dengan terumbu karang terutama bagi kehidupan ikan karang di perairan. Sehingga komposisi jenis ikan karang sesuai dengan tingginya tutupan ekosistem karang di stasiun III terutama pada persentase tutupan karang hidupnya. Famili dengan presentase tertinggi dari stasiun I dan stasiun III adalah famili Pomacentridae. Dari kedua stasiun, stasiun III 
yang memiliki persentase tertinggi hingga $69,24 \%$. Hal ini di duga karena dengan persentase karang hidup yang tinggi di stasiun III berkaitan dengan jenis ikan karang dari famili Pomacentridae untuk dapat mencari makan dan berkembang biak di areal terumbu karang hidup. Spesies yang mendominasi dari famili Pomacentridae adalah Chromis margaritifier dengan kebiasaan makan adalah karnivora dan jenis makanan adalah zooplankton dan telur ikan. Hal ini diduga karena pada stasiun III memiliki ekosistem terumbu karang yang beragam dan persentase karang hidup yang tinggi dari ketiga stasiun, dimana terumbu karang dijadikan tempat oleh ikan karang untuk mencari makan sekaligus untuk memijah dan tempat berlindung.

Pengelompokan ikan karang berdasarkan peranannya di stasiun I, stasiun II dan stasiun III di bagi menjadi ikan target, ikan indikator dan ikan mayor. Dari ketiga stasiun, ikan target pada stasiun III yang paling beragam, hal ini disebabkan karena faktor kondisi terumbu karang di stasiun III yang masih alami dan terjaga serta jauh dari aktivitas antropogenik jika dibandingkan dengan stasiun yang lainnya. Selain itu penyebab banyaknya ikan target pada stasiun III adalah tingginya tutupan karang pada stasiun III dibanding stasiun lainnya. Hal ini sesuai dengan pernyataan Muniaha (2017), bahwa faktor-faktor yang mempengaruhi kehadiran ikan (struktur komunitas dan kelimpahan ikan) di suatu komunitas terumbu karang, antara lain tinggi rendahnya persentase tutupan karang hidup dan zona habitat. Kemudian jika dilihat pada kelompok ikan indikator, kelimpahan individu tertinggi juga pada stasiun III dan kondisi tutupan karang pada stasiun III pun memiliki tutupan karang hidup yang tinggi sehingga tingginya tutupan karang hidup erat kaitannya dengan kelompok ikan indikator yaitu dari jenis ikan famili Chaetodontidae. Keunikan yang lain dari ikan Chaetodontidae adalah keberadaan, kelimpahan jenis dan individu ikan ini pada suatu perairan dapat memberikan gambaran kondisi terumbu karang setempat. Para ahli sepakat dalam menempatkan ikan kepe-kepe sebagai "spesies indicator" kondisi terumbu karang, karena ikan ini merupakan penghuni terumbu karang sejati (Suryanti et al., 2011). Tingginya jumlah individu ikan Chaetodontidae pada suatu perairan dapat mencerminkan bahwa kondisi suatu terumbu karang berada dalam keadaan baik, yang diidentifikasikan pula dengan tingginya tutupan karang hidup. Meningkatnya jumlah ikan akan berpengaruh terhadap kepadatan dan persaingan dalam memperoleh makanan dan tempat tinggal pada daerah terumbu karang (Suryanti et al., 2011).

Biomassa dicari untuk mengetahui massa ikan karang pada luasan di daerah penelitian. Biomassa ikan dibutuhkan untuk melihat tingkat produktivitas yang optimal pada kawasan konservasi. Dari ketiga stasiun, jumlah total biomassa tertinggi yaitu pada stasiun III yaitu sebanyak 1692,08 kg/ha (Tabel 5). Di duga tingginya biomassa ikan karang berkaitan dengan tingginya keanekaragaman yang berada di stasiun III (Gambar 5). Ikan yang beranekaragam yang disebabkan oleh ekosistem terumbu karang yang tinggi mengakibatkan tingginya ketersediaan makanan untuk ikan karang mengalami pertumbuhan. Sesuai dengan pernyataan Manembu et al. (2012), bahwa meningkatnya biomassa berkaitan dengan aktivitas makan yang dilakukan oleh organisme untuk melakukan pertumbuhan dan perkembangbiakan.

Rendahnya keanekaragaman pada stasiun II dibandingkan stasiun I dan stasiun III di duga karena banyaknya unsur abiotik yaitu patahan karang dan pasir hingga mencapai 53,92\% (Gambar 4) sehingga ikan yang berada pada daerah tersebut hanya didominasi oleh ikan karang yang kehidupannya bergantung pada organisme yang berada pada patahan karang. Dan stasiun III memiliki indeks keanekaragaman tertinggi dari stasiun lainnya yaitu sebesar 2,70. Hal ini sesuai dengan hasil dari persentase tutupan karang hidup dan variasi habitat yang berada pada stasiun III, dimana dari ketiga stasiun penelitian persentase tutupan karang hidup tertinggi terdapat pada stasiun III. Tingginya persentase karang hidup dan beragamnya variasi habitat menyediakan tempat bagi ikan karang untuk berlindung, mencari makan dan menjadikan ekosistem terumbu karang sebagai habitatnya. Menurut Muniaha (2017), jumlah mikrohabitat merupakan variasi habitat dari terumbu karang sehingga dapat dijadikan rumah atau tempat tinggal bagi ikan-ikan karang. Salah satu penyebab tingginya keragaman spesies di terumbu karang adalah karena variasi habitat yang terdapat di terumbu karang, dimana, semakin tinggi keanekaragaman terumbu karang maka jumlah kategori mikrohabitat akan semakin banyak. 
Pada hasil pengamatan, pengaruh persentase tutupan karang hidup terhadap Biomassa ikan karang dari hasil analisis korelasi menunjukkan adanya hubungan yang positif sangat kuat yaitu dengan diperolehnya korelasi (R) sebesar 0,9613 dan dari hasil koefisien determinasi, karang hidup mempengaruhi sebesar $92,42 \%$ terhadap biomassa ikan karang di seluruh setasiun penelitian di perairan manggis. Hal ini menunjukkan bahwa semakin tingginya persentase karang hidup dapat memengaruhi tingginya biomassa ikan karang di perairan tersebut. Berbeda dengan pengaruh persentase tutupan karang hidup dengan indeks keanekaragaman, hasil analisis korelasi menunjukkan adanya hubungan yang positif kuat dengan korelasi (R) sebesar 0,8087 dan hasil koefisien determinasi $\mathrm{R}^{2}$ sebesar 0,654. Hal ini menunjukkan bahwa meningkatnya persentase tutupan karang hidup berpengaruh terhadap variabel indeks keanekaragaman ikan karang sebesar 65,4\%. Jika dibandingkan, persentase tutupan karang hidup lebih berpengaruh terhadap biomassa ikan karang dibanding indeks keanekaragaman, hal ini di duga karena keanekaragaman ikan karang tidak hanya di sebabkan oleh tingginya tutupan karang hidup, tetapi karena adanya komponen lainnya yang menyebabkan tingginya keanekaragamn di daerah penelitian. Menurut Simarangkir et al. (2015) kondisi habitat ikan karang pada daerah terumbu karang tidak hanya terdiri dari karang, tetapi juga daerah berpasir, berbatu, daerah alga, lereng, tebing dan daerah perairan dangkal. Ikan karang jika dibandingkan dengan organisme yang lain di terumbu karang, merupakan jumlah yang paling banyak dan berlimpah, dengan keanekaragaman spesies sebanding dengan keanekaragaman spesies karang batu. Tingginya keragaman ini disebabkan terdapatnya variasi habitat yang ada di terumbu karang, dimana semua tipe habitat tersebut diisi oleh spesies ikan karang.

\section{Simpulan}

Indeks keanekaragaman pada stasiun penelitian berkisar antara 2,54 - 2,70, yang berarti keanekaragaman ikan karang termasuk dalam kategori sedang dan kestabilan komunitas sedang. Dan total biomassa ikan karang pada stasiun penelitian berkisar antara 186,17 - 1692,08 kg/ha. Tutupan karang hidup pada stasiun penelitian berkisar antara $3,83 \%-12,44 \%$, yang berarti tutupan karang hidup pada ketiga stasiun berada dalam kategori "Buruk". Terdapat korelasi positif sangat kuat antara kondisi karang hidup dengan biomassa ikan karang sebesar $\mathrm{R}=0,9613$ dan pengaruh sebesar $92,42 \%$. Sedangkan, hubungan antara kondisi karang hidup dengan keanekaragaman ikan karang memiliki korelasi yang positif kuat dengan $R=0,8087$ dan pengaruh sebesar $65,4 \%$.

\section{Ucapan terimakasih}

Terimakasih penulis ucapkan kepada Ni Wayan Ayu Astini Sari, Ni Made Pitria Menala Saputri, dan Ni Luh Febbi Mellani atas bantuannya dalam pengambilan data dilapangan. I Nyoman Giri Putra, Widiastuti dan I Dewa Nyoman Nurweda Putra atas kritik dan sarannya, Bapak Mangku LA selaku Ketua Nelayan Labuhan AmukKarangasem dan Fakultas Kelautan dan Perikanan Universitas Udayana atas fasilitas yang telah diberikan.

\section{Daftar Pustaka}

Arthana, I. W. (2009). Komunitas ikan karang di Pantai Sawangan dan Kutuh, Bali. Bumi Lestari, 9(2), 224-232.

Bergbauer, M., \& Kirschner, M. (2014). Reef Fishes of the Indo-Pacific. United Kingdom: John Beaufoy.

Dhahiyat, Y., Sinuhaji, D., \& Hamdani, H. (2017). Struktur Komunitas Ikan Karang Didaerah Transplantasi Karang Pulau Pari, Kepulauan Seribu [Community Structure of Coral Reef Fish in The Coral Transplantation Area Pulau Pari, Kepulauan Seribu]. Jurnal Iktiologi Indonesia, 3(2), 87-94.

Dhananjaya, I. G. N. A., Hendrawan, I. G., \& Faiqoh, E. (2017). Komposisi Spesies Ikan Karang Di Perairan Desa Bunutan, Kecamatan Abang, Kabupaten Karangasem, Bali. Journal of Marine and Aquatic Sciences, 3(1), 91-98.

Edrus, I. N., \& Syam, A. R. (2017). Sebaran Ikan Hias Suku Chaetodontidae di Perairan Karang Pulau Ambon dan Peranannya dalam Penentuan Kondisi Terumbu Karang.Jurnal Penelitian Perikanan Indonesia, 4(3), 1-10.

Freshcms. (2015). Dikeluhkan, pantai padangbai tercemar minyak. [online] DenPost: Denpasar. (http://denpostnews.com/2015/03/17/dikeluhkanpantai-padangbai-tercemar-minyak/), [diakses: 17 Maret 2012].

Hodgson, G. (1999). A global assessment of human effects on coral reefs. Marine Pollution Bulletin, 38(5), 345-355. 
Kulbicki, M., Guillemot, N., \& Amand, M. (2005). A General Aprooach to Length-Weight Relatsionship for New Caledonian Lagoon Fishes. Cybium 2005, 29(3), 235-252.

Manembu, I., Adrianto, L., Bengen, D. G., \& Yulianda, F. (2012). Distribusi karang dan ikan karang di kawasan reef ball Teluk Buyat Kabupaten Minahasa Tenggara. Jurnal Perikanan dan Kelautan Tropis, 8(1), 28-32.

Mardianto., Nur, A. I., \& Ramli, M. (2016). Studi ekologi bamboo laut (Isis hippuris) di perairan Tanjung Tiram Kecamatan Maramo Utara Kabupaten Konawe Selatan. Jurnal Manajemen Sumber Daya Perairan, 1(3), 323-332.

MENLH. (2001). Keputusan Menteri Lingkungan Hidup No.4/MENLH/02/2001 dalam Himpunan peraturan Perundang - undangan Bidang Pengelolaan lingkungan Hidup dan Pengendalian Dampak Lingkungan tentang Kriteria Baku Kerusakan Terumbu Karang. JakartaIndonesia: Era Otonomi Daerah Kementrian Lingkungan Hidup.

Mulyadi, M. (2011). Penelitian kuantitatif dan kualitatif serta pemikiran dasar menggabungkannya. Jurnal studi komunikasi dan media, 15(1), 128-137.

Muniaha, H., \& Nur, A. I. (2017). Studi kelimpahan ikan karang berdasarkan kondisi terumbu karang di Desa Tanjung Tiram Kabupaten Konawe Selatan. Jurnal Manajemen Sumber Daya Perairan, 2(1), 9-19

Nasution, S. (2016). Inventarisation of Coral Reef Fishes in the National Conservation Area, Anambas Islands, Province of Riau Islands. Jurnal Online Mahasiswa (JOM) Bidang Perikanan dan Ilmu Kelautan, 4(1), 1-19.
Perda Karangasem. (2012). Peraturan Daerah Kabupaten Karangasem Nomor 17 Tahun 2012, Tentang Rencana Tata Ruang Wilayah Kabupaten Karangasem Tahun 2012-2032. Karangasem, Indonesia: Pemerintah Daerah Daerah Kabupaten Karangasem.

Purnomo, T., \& Hariyadi, S. (2012). Kajian potensi perairan dangkal untuk pengembangan wisata bahari dan dampak pemanfaatannya bagi masyarakat sekitar (studi kasus Pulau Semak Daun sebagai daerah penunjang kegiatan wisata Pulau Pramuka Kabupaten Administrasi Kepulauan Seribu). DEPIK Jurnal Ilmu-Ilmu Perairan, Pesisir dan Perikanan, 2(3), 172-183

Rembet, U. N., Boer, M., Bengen, D. G., \& Fahrudin, A. (2011). Struktur komunitas ikan target di terumbu karang Pulau Hogow dan Putus-putus Sulawesi Utara. Jurnal Perikanan dan Kelautan Tropis, 7(2), 60-65.

Simarangkir, O. R., Yulianda, F., \& Boer, M. (2015). Pemulihan Komunitas Karang Keras Pasca Pemutihan Karang di Amed Bali.Jurnal Ilmu Pertanian Indonesia, 20(2), 158-163.

Subhan, B., Soedharma, D., Arafat, D., Maddupa, H., Rahmawati, F., Ervinia, A., Bramandito, A., Khaerudi, D., \& Ghozali, A. T. (2012). Pengaruh Cahaya Terhadap Tingkat Kelangsungan Hidup Dan Pertumbuhan Karang Lunak Lobophytum Strictum (Octocoralia: Alcyonacea) Hasil Transplantasi Pada Sistem Resirkulasi. Jurnal Teknologi Perikanan dan Kelautan, 3(2), 35-42.

Suryanti, S., Supriharyono, S., \& Indrawan, W. (2011). Kondisi Terumbu Karang dengan Indikator Ikan Chaetodontidae di Pulau Sambangan Kepulauan Karimun Jawa, Jepara, Jawa Tengah. Buletin Oseanografi Marina, 1(1), 106-119.

(c) 2018 by the authors; licensee Udayana University, Indonesia. This article is an open access article distributed under the terms and conditions of the Creative Commons Attribution license (http://creativecommons.org/licenses/by/3.0/). 